\title{
Corruption, Accounting Firm Size and Audit Fee Premium-Evidence from Chinese Listed Companies
}

\author{
Le Zhang \\ Management School, Jinan University, Guangzhou, China \\ Email: 15625176548@163.com
}

Received 18 July 2016; accepted 7 August 2016; published 10 August 2016

Copyright (C) 2016 by author and Scientific Research Publishing Inc.

This work is licensed under the Creative Commons Attribution International License (CC BY). http://creativecommons.org/licenses/by/4.0/

(c) (i) Open Access

\section{Abstract}

China is playing an increasingly important role in the global economy and the economic transformation becomes the most pressing need at this stage. "Corruption governance", and "anti-corruption" are hot topics which are discussed by people from all works of life. The main purpose of this paper is to examine the relationship between corruption and audit fee premium under the background of China's special institutional environment. Based on firms listed on the Shanghai and Shenzhen Stock Exchanges from 2007-2012, the paper verifies that compared with the domestic accounting firms, the international big four firms charge higher audit fees. More importantly, the empirical result finds that corruption has a positive effect on the relationship between firm size and audit fee premium. In other words, corruption governance will decrease the audit fee premium. This study contributes to improved understanding of the influence of anti-corruption wave in China.

\section{Keywords}

\section{Corruption, Accounting Firm Size, Audit Fee Premium, Audit Risk}

\section{Introduction}

After the 18th National Congress of the Communist Party of China, the anti-corruption wave sets off a new round of high tide and receives extensive attention of the society from all walks of life. But according to the Corruption Perceptions Index (CPI) which is published by Transparency International, we can see that the corruption perceptions index of China ranks between 70 - 80, in the middle or below average level in the world. As shown in Figure 1, from 2007 to 2012, China's corruption perceptions index scores have improved and still in 


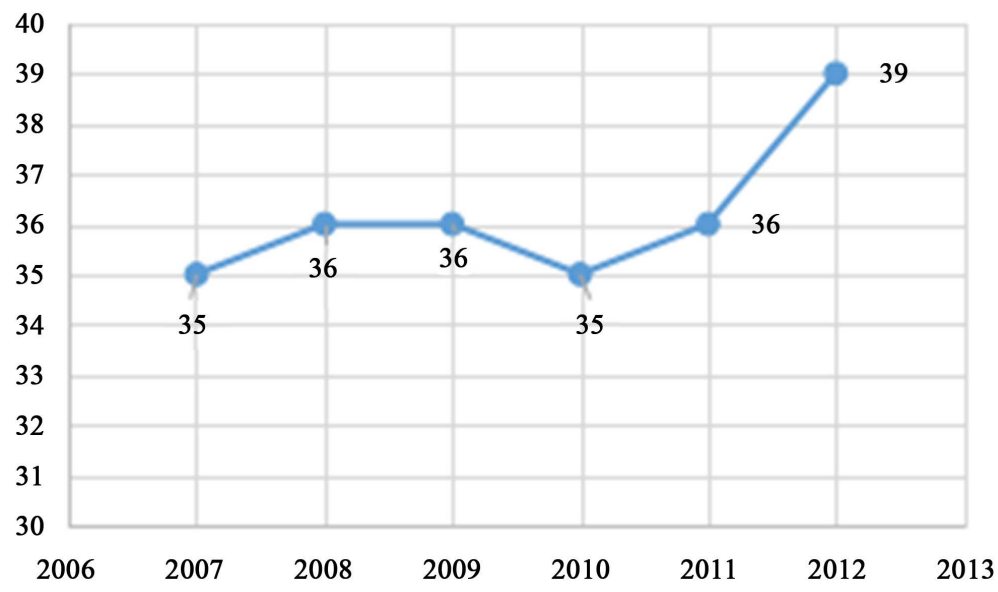

Figure 1. The CPI of China between 2007-2012.

the interval which represents a more severe corruption. (The corruption perceptions index score of 0 to 25 means extreme corruption; 25 to 50 says serious corruption; 50 to 80 expresses mild corruption and 80 to 100 signifies almost no corruption). At present, the institutional environment is not perfect in China which is in the period of economic transition; bribery is regarded as an effective way to fight for scarce resources, seek asylum and reduce the risk of it being investigated after violations for some listed companies and accounting firms. Predecessors' researches about corruption are mainly from macroeconomic perspective and corporate behavior perspective but fewer studies focus on the relationship between corruption and behavior choice of accounting firms. At the same time, media reports about high even incredible audit fees that the accounting firm charges are under heated discussion. The audit fees being charged by the international big four accounting firms are significantly higher than domestic firms and the gap can reach dozens of times. Why the audit fees have such a huge difference? Does the difference between international and domestic accounting firms audit fee disappear after taking the listed companies size and other company characteristic variables into consideration? The purpose of this paper is to find answers about the following two questions. One is after controlling company characteristic variables and audit opinion; the significant gap between accounting firms' audit fees will disappear or continue to exist. In other words, does audit fees premium phenomenon exist in China? The other one is to examine the relationship between corruption and audit fee premium and explain the internal mechanism.

\section{Literature Review}

\subsection{Corruption}

Institutional economics theories show that corruption is the inevitable outcome of the privilege and distortion of market mechanism. The government's over-interference of economic activity and excessive discretion lead to power rent-seeking behavior and huge opportunity of abuse of public power. At present, the majority of researches associated with corruption focus on macro level, such as the relationship between corruption and public expenditure or corruption and economic growth. Wu Junpei and Yao Lianfang (2008) found that corruption affected the country's public expenditure structure to a certain extent; Yang Feihu (2011) selected listed companies in China between 1980-2008 as the sample and made use of simultaneous equation including economic growth, public investment and corruption to carry on empirical research. The paper found that there was kuznets curve effects between corruption and economic growth in the field of public investment and the degree of corruption is close to a turning point in China. At the present stage, China should improve the supervision system and related regulations to reduce the possibility of power rent-seeking and adverse effects on economic growth from corruption. Kan Daxue and Lv Lianju (2015) used the systemic GMM method and found out that corruption not only aggravates environment pollution but also exacerbates environmental pollution of foreign of foreign.

Some scholars have focused on the influence of corruption from enterprise perspective. For enterprises, corruption or bribery has dual function including "Protection Money" and "Grease Money". "Protection money" 
refers to that the enterprise through corruption can make themselves from further extortion and plunder of government officials; "Protection money" refers to that to some extent corruption has the function of resource allocation (Leff, 1964; Lien, 1986). Huang Jiuli and Li Kunwang (2013) pointed out that in the control of the enterprise scale, productivity and ownership, the expenditure using to rent-seeking (e.g. business entertainment in the financial statements) can significantly promote the sales performance for the government departments and stateowned enterprises. Zhao Ying (2015) found that corruption has positive relationship with growth on sales and profit based on 2848 Chinese enterprises being investigated by World Bank in 2012. Xu Yekun and Li Weian (2016) examined the effects of corruption on investment of private enterprises and discuss the role of political connections. The results suggested that political corruption would stimulate the investment of private enterprises, and this effect mainly happened in politically connected enterprises.

\subsection{Accounting Firms Size and Audit Fee Premium}

As early as 1980s, there was a heated discussion in regard to the relationship between firm size and audit pricing among the western scholars. The discussion based on the following theoretical basis: monopoly power hypothesis, heterogeneous hypothesis and economies of scale hypothesis. Simunic (1980) took advantage of the data coming from big eight accounting firms and listed companies in the United States and didn't think that audit fee premium exist during the eight firms. Then, Chaney, Jeter and Shivakumar (2004) selected the cross listed company and private companies in Britain as the sample. The paper hold the opinion that there was not significant audit fee premium about the big five accounting companies. However, other scholars supported the opposite viewpoint. Francis and Simon (1987) pointed out that big eight accounting firms acquire audit fee premium in competitive market with small clients in Australia. Craswell, Francis and Taylor (1995) had a further study using 1484 listed companies in Australia. They found that compared with other accounting firms the big eight accounting firms won 30\% of the brand premium and degree of specialization had a positive correlation with audit fees within the big eight accounting firms.

The study of audit fee premium in China begun with the document published by China securities regulatory commission (CSRC) in 2001 which is about the information disclosure of companies issuing securities publicly. After ten years of research, the scholars have not come to consistent conclusion about the relationship between the accounting firm size and audit fee. Liu Bin, Ye Jianzhong and Liao Yingyi (2003) measured the size of accounting firms using big twenty and found that there was not a significant relationship among size and audit fee. Geng Jianxin and Fang Qiaoling (2006) supported their view and they used big four on behalf of the size in their empirical model. However, other scholars put forward different opinions. Wu Lina (2003) analyzed the influence factors of financial audit fee of 282 companies by means of Simunic model and modified Simunic model respectively. The empirical results of this paper showed that the size of accounting firms which was measured by big five had significant impact on the annual financial audit fees. Qi Jiangna, Chen Huilin and Zhang Yang (2004) pointed out that the listed companies in China were willing to pay for the audit fee premium so that they could invite the big four accounting firms to provide audit service. Shen Xiaoyan and Wen Guoshan (2008) using firms listed on the Shanghai and Shenzhen Stock Exchanges from 2002-2006 came to the conclusion that not only the international big four accounting firms but also China domestic accounting firms having larger scale charged audit fee premium. They thought the premium derived from the scale effect and brand reputation. Wang Liangcheng and Chen Hanwen (2010) pointed out that big accounting firms charged higher audit fee compared with small accounting firms and the audit fee premium became vanished with good legal environment. Cai Chun, Sun Ting and Ye Jianming (2011) investigated the audit fee of local accounting firms and international big four accounting firms during the period of 2002-2008 and found that audit fee premium of big four is increasing. Shen Hui and Xiao Xiaofeng (2013) proved big accounting firms will charge a higher audit fee than small accounting firms. In order to cope with the increased audit risk auditor need to raise audit fee to compensate for additional accounting procedure expenditure and higher audit risk cost. Wang Yafang and Huang Yuting (2015) showed that supply chain auditors of big four certified public accountant firms can obtain fees premium and the premium depends on client location and auditor-client tenure. In particular, Deloitte \& Touche is the most significantly associated with audit fees premium. Xing Weiquan (2015) agreed that international big four charged audit fee premium and found that the adoption of new accounting standards increased the audit fee premium.

In previous literature, scholars had a multi-angle discussion about the relationship between accounting firm size and audit fee audit and internal causes. The behavior of accounting firm and listed company has been influ- 
enced by the environment. However, little literature focuses on the corruption which is an important character in transition economy and its affect in auditing field. This paper tries to find and explain the relationship between corruption, accounting firm size and audit fee premium.

\section{Research Design}

\subsection{Hypothesis Development}

The cost function of audit activities is composed of two parts: the auditor's effort cost and the expected future loss. The cost of efforts is closely related to the size of audit object, the complexity of audit services and other firm characters. The expected future losses is determined by the auditor's legal responsibility and the possibility of being investigated or punished when they take a lower standard to the listed companies' financial statements. The accounting firms need to take efforts cost and expected future loss into consideration and aim at realizing the maximization of enterprise's benefits.

International big four accounting firms possess many years of experience about audit services and have highquality team of auditors. Relative to domestic accounting firm with various audit quality, big four accounting firms are able to provide higher quality audit service and more persuasive audit report. In order to ensure the firm's audit quality and maintain the brand reputation, the auditors working for the big four may do more substantive tests and compliance tests when they conduct an engagement. As a result, the efforts cost increases along with inputting more human resource and other resources. In addition, from the perspective of the insurance hypothesis of auditing requirements, the risk premium of big four accounting firms is much higher than the general accounting firm. The expected losses including direct and indirect losses of inappropriate audit opinion are likely to be higher than other accounting firms. Thus the expected losses, especially indirect losses, may lead to audit fees premium.

Hypothesis 1: After controlling other variables, audit fees are significantly and positively correlated with size of the accounting firms. Namely big four accounting firms win audit fees premium relative to other accounting firms in China.

To some extent, corruption or bribery implies that formal institutions are inadequate. In China, the government plays an important role in economic development and bribery becomes a effective method to obtain advantages and avoid punishment. When the corruption phenomenon exist widely, the listed companies favor to invite big four accounting companies to implement audit procedures in order to deliver a positive signal. Comparing with other accounting firms, the audit reports published by the big four accounting firms are easier to get the belief of investor. They are in strong position in the audit fee negotiations and charge high audit fee for audit services. In addition, high degree of corruption may send a signal that the law system is not perfect and bribery can reduce the possibility of being investigated and punished. The audit risk about publishing audit reports is relatively low and the accounting firms with small market share may charge lower audit fee to attract customers. Thus, the audit fee gap between international big four and domestic accounting firms widens.

Hypothesis 2: After including the degree of corruption into model, it has a significantly positive effect on the audit fee premium.

\subsection{Variables and Models}

The variables used in the analysis are described in Table 1. Dependent variables of the paper is annual audit fee paid by the listed companies. In particular, the audit fee using in this paper is not a broad concept and it refers to the compensation giving for accounting firms due to statements audit service, not including travel expenses, entertainment expenses, consulting fees and so on.

This paper uses a dummy variable to measure the scale of accounting firms. The accounting firms are divided into two group-international four big accounting firms and local audit firms in China. The dummy variable Big4 that equals to one if the listed companies buy audit service from international big four firms and zero if listed companies buy audit service from local audit firms in China.

In some literature, they measure the degree of corruption by means of standardized index. The indexes which are more typical among them are Business International Index provided by World Bank and Corruption Perceptions Index published by Transparency International. But I think that subjective cognitive data may be influenced by the personal experience and judgments and the objective data from China can be more appropriate. 
Table 1. The definition of variables.

\begin{tabular}{cc}
\hline Variables & Definition \\
\hline Lnfee & $\begin{array}{c}\text { Logarithm of annual audit fees of listed companies } \\
\text { Big4 } \\
\text { Cor } \\
\text { Size } \\
\text { Eev } \\
\text { Rec } \\
\text { Inv } \\
\text { ans zero if listed company buy audit service from local audit firms in China. } \\
\text { Amount of duty crime cases accepting by national prosecuting authority } \\
\text { LPS } \\
\text { Fpinal total debt/total assets of the listed companies } \\
\text { Final net receivables/total assets of the listed companies } \\
\text { Net ending inventory/total assets of the listed companies } \\
\text { Net income/total number of ordinary shares of the listed companies } \\
\text { Equals one if the Chinese listed companies receive standard unqualified } \\
\text { audit opinion and zero if listed companies receive modified audit opinion }\end{array}$ \\
\hline
\end{tabular}

The paper uses the amount of duty crime cases accepting by national prosecuting authority to represent the degree of corruption and this method is accepted in Wu Yiping and Rui Yin (2010). According to order of magnitudes, the amount of duty crime cases need to be handled simply.

The control variables in this paper is decided in reference to previous literature and combining with the theme of this article. In general, the scale of listed company has positive relationship with audit fee because that the auditor need to pay out more efforts in the process of audit when the company has larger scale. Lev is used to measure asset-liability ratio, which is on behalf of company's solvency and financial risk. In the balance sheet, accounts receivable and notes receivable are vital projects during the audit. Receivables not only take up a large part of current assets, but also are more likely to have untrue statement which need to be discovered by substantive testing and compliance testing. Thus receivables ratio has positive influence on the audit fee. EPS is used to reflect the profitability of listed company and has negative relationship with audit fee. Opinion is comprehensive evaluation of financial reports from the accounting firms based on a series of audit evidence and audit procedures. The listed company attaches great importance to the audit opinion because it is able to sent signal to the market and affects investors' decision. Previous research showed that modified audit opinion is positive related to financial risk of the listed company as well as loss exposure which auditor need to undertake. Thus the accounting firm will charge higher audit fee if the listed company received a modified audit opinion.

In order to verify the hypothesis I construct two empirical models. Model 1 is used to verify the relationship between size of accounting firm and audit fee. I expect the sign of Big4 is positive. Model 2 is used to verify hypothesis2 and I expect the sign of Big4*Cor is positive.

$$
\begin{aligned}
& \text { Lnfee }=\alpha_{0}+\alpha_{1} * \operatorname{Big} 4+\alpha_{2} * \operatorname{Size}+\alpha_{3} * \operatorname{Lev}+\alpha_{4} * \operatorname{Rec}+\alpha_{5} * \operatorname{Inv}+\alpha_{6} * \text { EPS }+\alpha_{7} * \text { Opinion_lag }+\varepsilon \\
& \text { Lnfee }=\beta_{0}+\beta_{1} * \operatorname{Big} 4+\beta_{2} * \operatorname{Cor}+\beta_{3} * \operatorname{Big} 4 * \operatorname{Cor}+\beta_{4} * \operatorname{Size}+\beta_{5} * \text { Lev } \\
& +\beta_{6} * \operatorname{Rec}+\beta_{7} * \operatorname{Inv}+\beta_{8} * \operatorname{EPS}+\beta_{09} * \text { Opinion_lag }+\varepsilon
\end{aligned}
$$

\subsection{Sample and Data Source}

The sample of this paper is firms listed on the Shanghai and Shenzhen Stock Exchanges from 2007-2012. In the empirical analysis, I exclude firms flagged with ST and *ST, which denote special treatment due to an irregularity in financial reporting and negative profits for two or three consecutive years. I also exclude firms in the finance industry because of their unique accounting standards. Our final sample comprises 7724 firm-year observations. The information on audit fee, audit opinion, accounting firm and firm financial characteristics come from the Chinese Stock and Market Accounting Research (CSMAR) database. And i collect the information on corruption by "Procuratorial Yearbook of China”. Meanwhile, to alleviate the influence of outlier on parameter estimation, this paper winsorize all the variables representing characteristics of listed companies for $1 \%$. 


\section{Empirical Results and Analysis}

\subsection{Descriptive Statistics}

Table 2 presents summary statistics on the variables used in our econometric analyses. The mean of audit fee after taking the logarithm is 13.303, which represents that the fee paying for the accounting firms averages RMB 600 thousand. The max and min of Lnfee are 15.384 and 12.134 respectively which reflect that audit fee has obvious difference among listed company. The mean of Big4 is 0.049 and this suggests that about 5 percent of non-financial listed company invites international big four accounting firms to providing audit service and most of the company choose domestic accounting firms. The duty crime is the corrupt centralism manifests and during the sample period the national prosecuting authority accepted 46 thousand to 52 thousand duty crime cases each year. Among the control variables, the mean of asset-liability ratio is 0.502 . This results indicates that the financial risk of listed company in China is not high. On average, the sum of receivables and inventory account for about $30 \%$ of the company's assets. Thus, they become emphasis in the process of auditing. The accounting firms give standard unqualified audit opinion to the vast majority of listed company and less than $7 \%$ of the audit object receive modified opinion.

In addition, I exam the multicollinearity problems by mean of correlation coefficient and variance inflation factor. The variance inflation factor of each variable using in the model is less than 10 . Therefore, there is not serious multicollinearity problem in the paper and the empirical results is relatively reliable.

\subsection{Regression Results}

Model (1) in Table 3 is used to test the relationship between the accounting firm size and audit fee. It can be seen that the coefficient on Big4 is 0.684 and is statistically significant at the 1\% level. It suggests that compared with accounting firms established in China the international big four firms charge higher audit fee and the result is consistent with the expectations. The premium may drive from brand premium and risk premium. The scale of listed company, asset-liability ratio and receivables ratio have significantly positive correlation with audit fee, consistent with previous literature. The coefficient on Opinion_lag is -0.197 and significant at the $1 \%$ level. This result shows that accounting firm will charge higher audit fee for the listed company which receives modified audit opinion last year because auditors will exert more efforts and take more risk.

Model (2) in Table 3 reflects the degree of corruption and its interaction with accounting firm size have significant relationship with audit fee. The empirical results indicate that the coefficient on interaction of accounting firm size and degree of corruption is 0.203 and significant at the $5 \%$ level. Compared with lower degree of corruption, the international big four accounting firms obtain a greater audit premium when the degree of corruption is higher. Thus the premium will shrink along with the decreasing of degree of corruption due to the improvement of determination to anti-corruption. The symbol of Cor is minus and significant at $1 \%$ level. Most of the control variables have the same symbol and significance level with Model (1).

Table 2. Sample descriptive statistic.

\begin{tabular}{|c|c|c|c|c|c|}
\hline Variables & Mean & Standard deviation & Minimum & Median & Maximum \\
\hline Ln fee & 13.303 & 0.590 & 12.134 & 13.218 & 15.384 \\
\hline Big4 & 0.049 & 0.217 & 0 & 0 & 1 \\
\hline Cur & 4.906 & 0.224 & 4.683 & 4.997 & 5.196 \\
\hline Size & 21.704 & 1.271 & 18.555 & 21.610 & 25.768 \\
\hline Lev & 0.502 & 0.273 & 0.041 & 0.493 & 1.867 \\
\hline $\operatorname{Rec}$ & 0.116 & 0.105 & 0 & 0.091 & 0.442 \\
\hline Inv & 0.175 & 0.164 & 0 & 0.134 & 0.756 \\
\hline EPS & 0.311 & 0.443 & -0.932 & 0.236 & 2.160 \\
\hline Opinion_lag & 0.939 & 0.240 & 0 & 1 & 1 \\
\hline
\end{tabular}


Table 3. Regression results of audit fee premium.

\begin{tabular}{|c|c|c|c|c|}
\hline \multirow{2}{*}{ Variables } & \multicolumn{2}{|c|}{ Model (1) } & \multicolumn{2}{|c|}{ Model (2) } \\
\hline & Coefficient & T value & Coefficient & $\mathrm{T}$ value \\
\hline Big4 & $0.684^{* * * *}$ & 31.91 & -0.352 & -0.79 \\
\hline Cor & & & $-0.218^{* * *}$ & -10.65 \\
\hline Big $4^{*}$ Cor & & & $0.213^{* *}$ & 2.35 \\
\hline Size & $0.304^{* * *}$ & 72.42 & $0.297^{* * *}$ & 70.78 \\
\hline Lev & $0.059^{* * * *}$ & 3.06 & $0.084^{* * *}$ & 4.39 \\
\hline Rec & $0.123^{* * *}$ & 2.88 & $0.075^{*}$ & 1.76 \\
\hline Inv & $-0.072^{* * *}$ & -2.56 & $-0.073^{* * *}$ & -2.66 \\
\hline EPS & -0.010 & 0.96 & $0.010^{* * *}$ & 0.99 \\
\hline Opinion_lag & $-0.197^{* * *}$ & -9.02 & $-0.180^{* * *}$ & -8.30 \\
\hline Intercept & $6.820^{* * *}$ & 81.81 & 7.999 & 57.87 \\
\hline Adj $R^{2}$ & \multicolumn{2}{|c|}{0.571} & \multicolumn{2}{|c|}{0.577} \\
\hline
\end{tabular}

To increase the reliability and robustness of empirical results, this paper selects the total audit fee including travel expense and so on to do further testing. In untabulated results, the coefficient on Big4 and its interaction with Cor are significantly positive. This results indicates that international big four accounting firms win audit fee premium and the degree of corruption in China expand the premium.

\section{Conclusion}

Through the research on accounting firm size, audit fee and degree of corruption, this paper concludes that: First of all, the international big four accounting firms charge higher audit fee than accounting firm established in China. In other word, audit fee premium exists in China. Then the degree of corruption has significantly negative correlation with audit fee. Last but not least, the degree of corruption has significantly positive influence on the relationship between accounting firm size and audit fee. Namely the difference in audit fee between international and local accounting firms will shrink when the degree of corruption is low. The conclusions in this paper have theoretical and practical significance. On one hand, the research on the relationship between corruption and audit fee premium will enrich the literature about corruption. On the other hand, the finding helps to improve understanding of the influence of anti-corruption wave in China. The constant improvement of legal system and unceasing enhancement of supervision consciousness driving from anti-corruption will have widespread influence on enterprise behavior.

\section{References}

Cai Chun, Sun Ting, \& Ye Jianming 蔡春, 孙婷, 叶建明 (2011). Study on the Effect of China’s Local Accounting Firms Mergers-Based on the Audit Fee Premium of Big Four 中国内资会计师事务所合并效果研究一一基于国际四大审计 收费溢价的分析. Accounting Research, 1, 83-89.

Chaney, P. K., Jeter, D., \& Shivakumar, L. (2004). Self-Selection of Auditors and Audit Pricing in Private Firms. Accounting Review, 79, 51-72. http://dx.doi.org/10.2308/accr.2004.79.1.51

Craswell, A. T., Francis, J. R., \& Taylor, S. L. (1995). Auditor Brand Name Reputations and Industry Specialization. Journal of Accounting and Economics, 20, 297-322. http://dx.doi.org/10.1016/0165-4101(95)00403-3

Francis, J. R., \& Simon, D. T. (1987). A Test of Audit Pricing in the Small-Client Segment of the U.S. Audit Market. The Accounting Review, 62, 145-157.

Geng Jianxin, \& Fang Qiaoling 耿建新, 房巧玲 (2006). Comparative Study about Audit Fee of International Big Four and Local Accounting Firms-Evidence from Securities Auditing Market in China 国际四大所与我国本土大所审计收费比 较研究——来自我国证券审计市场的初步证据. Contemporary Finance and Economics, 1, 113-127. 
Huang Jiuli, \& Li Kunwang 黄玖立, 李坤望 (2013). Eat-Drink, Corruption and Firm’s Purchase Order 吃喝, 腐败与企 业订单. Economic Research Journal, 6, 71-84.

Kan Daxue, \& Lv, Lianju 阚大学, 吕连菊 (2015). Foreign Trade, Regional Corruption and Environmental Pollution: An Empirical Study Based on Dynamic Panel Data 对外贸易, 地区腐败与环境污染——基于省级动态面板数据的实证 研究. World Economy Study, 1, 120-126.

Leff, N. H. (1986). Economic Development through Bureaucratic Corruption. American Behavioral Scientist, 8, 8-14. http://dx.doi.org/10.1177/000276426400800303

Lien, D. H. D. (1986). A Note on Competitive Bribery Games. Economic Letters, 22, 337-341. http://dx.doi.org/10.1016/0165-1765(86)90093-5

Liu Bin, Ye Jianzhong, \& Liao Yingyi 刘斌, 叶建中, 廖莹毅 (2003). An Empirical Study on Determinants of the Audit Fees in China-Evidence from Listed Company in Shanghai and Shenzhen Stock Market in 2001. 我国上市公司审计收 费影响因素的实证研究——深沪市 2001 年报的经验证据. Audit Research, 1, 44-47.

Qi Jiangna, Chen Huilin, \& Zhang Yang 漆江娜, 陈慧霖, 张阳 (2004). Accounting Firm Size, Brand, Price and Audit Quality—The Audit Fee and Audit Quality of International Big Four Accounting Firms in Chinese Auditing Market 事务 所规模，品牌，价格与审计质量——国际“四大”中国审计市场收费与质量研究. Audit Research, 3, 59-65.

Shen Xiaoyan, \& Wen Guoshan 沈小燕, 温国山 (2008). The Size, Brand Name Reputation and Audit Fee Premium of Accounting Firms 会计师事务所规模, 品牌声誉与审计费用溢价. Journal of Nantong University (Social Sciences Edition), 5, 119-126.

Shen Hui, \& Xiao Xiaofeng 沈辉, 肖小凤 (2013). Accounting Firm’s Legal Liability and Audit Fee Premium 会计师事 务所法律责任与审计收费溢价. Journal of Audit and Economics, 6, 38-43.

Simunic, D. A. (1980). The Pricing of Audit Services: Theory and Evidence. Journal of Accounting Research, 18, 161-190. http://dx.doi.org/10.2307/2490397

Wang Liangcheng, \& Chen Hanwen 王良成, 陈汉文 (2010). Legal Environment, Accounting Firm Size and Audit Pricing 法律环境，事务所规模与审计定价. Finance and Trade Economics, 4, 69-75.

Wang Yafang, \& Huang Yuting 王雅芳, 黄钰婷 (2015). An Analysis of Audit Fees Premiums: Evidence from Supply Chain Auditor Choice 供应链审计师选择之审计收费溢价分析. Contemporary Accounting Review, 8, 99-119.

Wu Junpei, \& Yao Lianfang 吴俊培, 姚莲芳 (2008). Corruption and the Departure in the Composition of Public Expenditure 腐败与公共支出结构偏离. China Soft Science, 44, 8-15.

Wu Lina 伍利娜 (2003). Empirical Research on the Forming Determinants of the Audit Fees_Evidence from Audit Fee Disclosure of Chinese Listed Company for the First Time 审计定价影响因素研究——来自中国上市公司首次审计费 用披露的证据. China Accounting Review, 7, 113-128.

Wu Yiping, \& Rui Yin 吴一平, 茌荫 (2010). Corruption, Marketization and the Economic Growth of China 地区腐败, 市场化与中国经济增长. Management World, 11, 10-17.

Xing Weiquan 刑维全 (2015). Whether International Convergence of Accounting Standards Improve the Audit Fee Premium?-From an Analysis of the International Big Four Accounting Firm 会计准则国际趋同是否提高了审计溢价一 一基于“四大”会计师事务所的数据分析. Communication of Finance and Accounting, 31, 116-118.

Xu Yekun, \& Li Weian 徐业坤, 李维安 (2016). Does Corruption Grease or Sand the Wheels of Private Investment? 腐败: 私有投资的润滑剂还是绊脚石? Comparative Economic and Social Systems, 2, 75-88.

Yang Feihu 杨飞虎 (2011). A Empirical Analysis on the Corruption in Public Investment and Economic Growth Based on China from 1980 to 2008 公共投资中的腐败问题与经济增长一一基于中国 1980-2008 年的实证分析. Economic Management Journal, 8, 162-169.

Zhao Ying 赵颖 (2015). Corruption and Enterprise Growth: Empirical Evidence from China 腐败与企业成长: 中国的经 验证据. Economic Perspectives, 7, 35-49. 


\section{Submit or recommend next manuscript to SCIRP and we will provide best service for you:}

Accepting pre-submission inquiries through Email, Facebook, LinkedIn, Twitter, etc.

A wide selection of journals (inclusive of 9 subjects, more than 200 journals)

Providing 24-hour high-quality service

User-friendly online submission system

Fair and swift peer-review system

Efficient typesetting and proofreading procedure

Display of the result of downloads and visits, as well as the number of cited articles

Maximum dissemination of your research work

Submit your manuscript at: http://papersubmission.scirp.org/ 